\title{
Management of tillering in the production of flower stems of heliconia cultivated in pots
}

\author{
Jobson Paixão de Amorim Coelho ${ }^{*}$, Eliezer Santurbano Gervásio², Teógene Souza de Sá', \\ Márkilla Zunete Beckmann Cavalcante ${ }^{3}$, Sabrina Gomes de Souza ${ }^{4}$
}

\author{
'Federal University of the São Francisco Valley, Petrolina, Brazil \\ 2University of São Paulo, São Paulo, Brazil \\ ${ }^{3}$ Paulista State University, São Paulo, Brazil \\ ${ }^{4}$ Rural Federal University of Pernambuco, Serra Talhada, Brazil \\ *Corresponding author, email: jobson.amorim@yahoo.com.br
}

\begin{abstract}
Potted cultivation of tropical flowers presents good projections for the northeastern region of Brazil; however, it still faces some peculiarities regarding conduction and management. The objective of this study was to evaluate the effect of tillering on the production of Heliconia psittacorum L.f. cv. Red Opal, grown in flowerpot. The experiment was carried out in a protected environment at the Campus of Agricultural Sciences (CCA) of UNIVASF, Petrolina - PE, Brazil, between 2014 and 2016. A completely randomized design was used, with four tiller densities per pot $(4,8,12$ and 16 tillers) and eight replications, totaling 32 plots. The irrigation system was automated and monitored by weighing lysimetry. Were evaluated: efficiency of water use (EUA); harvested flower stems ( $\mathrm{HC}$ ); ratio of harvested stems and number of tillers (HC / NP); number of leaves (NF); duration of vegetative (DFV) and productive phases (DFP); total cycle (CT); floral stem length (CHF); floral stem diameter (DH), bracts length (CB) and equivalent diameter of the collar (DECH). The results were subjected to regression test. The EUA was higher in the density of 16 tillers pot $^{-1}$; the $\mathrm{HC}$ variable presented an increasing linear trend; a decreasing linear trend was detected for HC/NP, NF, DFP, DH, CB and DECH. The number of tillers in the pot does not limit the emission of floral stems. However, the quality of these is inversely proportional to the tiller density.
\end{abstract}

Keywords: intensive cultivation, profile density, cutting flower, heliconia psittacorum, floral quality

\section{Introduction}

Floriculture stands out for its diversification and diffusion of new technologies, despite the more concentrated consumption within the population with greater purchasing power. Nevertheless, the per capita consumption of flowers by Brazilians increased from US $\$ 4.70$ in 2008 to US\$8.00 in 2014 (Ibraflor, 2016).

The cultivation of tropical flowers presents good projections for the Northeast region of Brazil (Junqueira \& Peetz, 2008), with a great part of this farming being represented by the heliconias. These plants are characterized for its exotic beauty and present several regionalized common names in Brazil, such as bananeira-de- jardim and paquevira (Paiva \& Almeida, 2014). Some climatic factors present influence in the growth of heliconias, such as solar irradiance, humidity and temperature. These plants present high water demand, with average evapotranspiration over $2 \mathrm{~mm}$ day $^{-1}$ (Gomes et al., 2006; Gondim et al., 2008; Felisberto et al., 2015).

Pot cultivation holds some peculiarities and presents itself as a worldwide tendency. However, there is still little information in literature concerning heliconias (Nomura, 2008). The space limitation in pot cultivation infers an optimization of irrigation, which is more frequent, besides requiring a substrate with porosity over $85 \%$ 
(Carrijo et al., 2002). The same authors affirm that the coconut husk powder is an excellent material for flower cultivation without soil.

Some works related to pot cultivation of heliconias with free tillering did not succeed in the emission of floral stems, or even presented a reduced emission, without mention of the authors on the cause of the non-flowering (Souza et al. 2009). Sousa et al. (2011) attributed the little flowering to water salinity, although it did not interfere in tillering. Santos et al. (2012) attributed the non-flowering to the low level of applied phosphorus (P).

Gervásio \& Melo Junior (2014) when evaluating different levels of water depletion in organic substrate in pot cultivation of heliconias, obtained a high tillering, reaching up to 25 tillers per vase. It is believed that the high tillering limited the production of floral stems. In view of this, a preliminary experiment was performed, in which the free tillering and the maintaining of ten tillers per vase were evaluated, observing the non-flowering and the emission of floral stems, respectively. Therefore, the high number of tillers implies in a competition for light, hardening the emission of the floral stem.

Based on these data, an experiment was performed with the aim of evaluating Heliconia psittacorum L.f. cv. Red Opal as to the tiller density per pot and its relation with the production of floral stems, aiming to determine the ideal number of tillers that promotes the highest production within the quality standards demanded by the market.

\section{Material and Methods}

The work as conducted in the Campus of Agrarian Sciences (CCA) of the Federal University of the São Francisco Valley (UNIVASF), located in the municipality of Petrolina/PE $\left(40^{\circ} 24^{\prime} 22^{\prime \prime} \mathrm{W}\right.$, and 9०30'56" S) at $380 \mathrm{~m}$ above sea level. The climate of the region is of the BSwh' type, according to the classification of Köppen.

The experiment was installed in a protected environment, with $12 \mathrm{~m}$ length (east/ west), $6 \mathrm{~m}$ width and $2.5 \mathrm{~m}$ height. A $50 \%$ shading screen was utilized as covering, based on the recommendation of Souza et al. (2016) for the production of Heliconia psittacorum.
The experimental design was completely randomized, with four treatments and eight replications, totaling 32 plots (one vase per plot). The treatments were represented by the different tiller densities $(4,8,12$ and 16 tillers per pot). These densities were maintained over the entire experimental period, eliminating the additional tillers through constant prunings. Extra pots were distributed around the floor area, which had the number of tillers under control.

The substrate utilized for cultivation was the coconut husk powder. Samples of this material, dried in forced air-drying oven for 72 hours, were subjected to characterization as to their physical-hydric properties in the hydraulics laboratory of the Campus of Agrarian Sciences (CCA) of the UNIVASF (Table 1).

Plastic pots with $37.4 \mathrm{~cm}$ diameter, 19.1 $\mathrm{cm}$ height and 21 liters of volumetric capacity were utilized. In all pots a thin layer of gravel with particle size between 9.5 and $19 \mathrm{~mm}$ (3.21 $\mathrm{kg}$ ) was added aiming to facilitate the drainage process. Afterwards, the pots were filled with 3.9 $\mathrm{kg}$ of substrate and distributed in the spacing of $0.5 \mathrm{~m}$ between pots and $0.85 \mathrm{~m}$ between lines, with both measures taken from the center of the pot. At 199 days after planting (DAP), the spacings between pots and lines were altered, both assuming $1 \mathrm{~m}$.

Aiming to decrease the excess of salts within the substrate, seven water applications of ten liters were applied in each pot, reducing the electrical conductivity (CE) of the drained solution from the mean value of $9.82 \mathrm{dS} \mathrm{m}^{-1}$ to $0.33 \mathrm{dS} \mathrm{m}^{-1}$.

An irrigation system through dripping was utilized, consisting of: a self-compensating emitter with nominal flow rate of $4 \mathrm{I} \mathrm{h}^{-1}$; a 4 way "manifold" connector, to which four arrow type drip emitters were coupled, aiming to improve the water distribution in the pot. For the pressurization of the irrigation system a KSB motor pump set model C7500 and 75 Cv was utilized. The assay of distribution uniformity (UD) of water through the system was performed, revealing the value of $97.75 \%$.

The irrigation system was automatized through the technique of weighing lysimetry (Gervásio \& Melo Junior, 2014), utilizing one 
lysimeter per treatment to determine the irrigation moment. The lysimeter was programed to irrigate when a water consumption equivalent to $5 \%$ of the maximum water retention capacity of the vase occurred (payload capacity). A A202 datalogger was utilized for registering the weights of the monitored pots, storing data every ten minutes. This allowed to quantify the irrigation frequency in each treatment.

The volume of water and nutritive solution applied in each treatment throughout the experimental period was computed by hydrometers through daily readings. From the volume it was possible to estimate the amount of macro and micronutrients applied according to the equation proposed by Rhoades et al. (1992), with adaptations (equation 1). The adaptation of the equation was necessary for disregarding the soluble solids present in the irrigation water.

$$
\mathrm{TSD}=640 .(\mathrm{CEs}-\mathrm{CEa})
$$
$\left(\mathrm{mg} \mathrm{L} \mathrm{L}^{-1}\right)$ :

In which: TSD - Total of dissolved solids

CEs - Electrical conductivity of fertilizer

Table 1. Physical-hydric characterization of the coconut husk powder utilized in the pot cultivation of H. psittacorum L.f. cv. Red Opal in Petrolina/PE.

\begin{tabular}{|c|c|c|}
\hline Density $\left(\mathrm{kg} \mathrm{m}^{-3}\right)$ & & 79.00 \\
\hline Porosity (\%) & & 84.45 \\
\hline & Tensile strength (kPa) & Humidity $\left(\mathrm{m}^{3} \mathrm{~m}^{-3}\right)$ \\
\hline & 1 & 54.60 \\
\hline \multirow[t]{2}{*}{ Water retention } & 5 & 39.57 \\
\hline & 10 & 37.00 \\
\hline & & Percentage (\%) \\
\hline Aeration capacity & & 29.85 \\
\hline Readily available water & & 15.04 \\
\hline Water reserve & & 2.57 \\
\hline Available water & & 17.60 \\
\hline \multirow[t]{5}{*}{ Remaining water } & & 37.00 \\
\hline & Sieve $(\mathrm{mm})$ & Material percentage (\%) \\
\hline & $\geq 4,00$ & 2.05 \\
\hline & $3.35 \leq x \leq 4.00$ & 0.46 \\
\hline & $2.00 \leq x \leq 3.35$ & 6.21 \\
\hline \multirow[t]{5}{*}{ Particle size } & $1.40 \leq x \leq 2.00$ & 9.46 \\
\hline & $1.00 \leq X \leq 1.40$ & 11.30 \\
\hline & $0.50 \leq x \leq 1.00$ & 34.95 \\
\hline & $<0.5$ & 35.57 \\
\hline & TOTAL & 100.00 \\
\hline
\end{tabular}

Table 2. Characteristics of the fertilizers utilized in the cultivation of H. psittacorum L.f. cv. Red Opal in Petrolina/PE.

\begin{tabular}{cccccccccc}
\hline Fertilizer & $\mathrm{N}(\%)$ & $\mathrm{P}_{2} \mathrm{O}_{5}(\%)$ & $\mathrm{K}_{2} \mathrm{O}(\%)$ & $\mathrm{Mg}(\%)$ & $\mathrm{S}(\%)$ & $\mathrm{Zn}(\%)$ & $\mathrm{Mn}(\%)$ & $\mathrm{B}(\%)$ & $\mathrm{Mo} \mathrm{( \% )}$ \\
\hline $\mathrm{MX01}$ & 14 & 10 & 28 & 1 & 1.3 & 0.1 & 0.05 & 0.03 & 0.005 \\
$\mathrm{MX07}$ & 20 & 5 & 20 & 1 & 1.3 & 0.1 & 0.05 & 0.03 & 0.005 \\
\hline
\end{tabular}


Tillering management occurred from daily observations of the number of tilers emitted per pot, with these being properly identified (number of the tiller and date of emission). In this manner, tiller density was maintained for each treatment. Once achieved the maximum number of tillers in the pot, the remaining tillers emitted were eliminated through prunings close to the substrate. Only on the occasion of harvest of one or more tillers in the pot the emission of a new tiller was allowed.

The experiment comprised two productive cycles. The first cycle was represented by the first emitted tillers. From the collection of the floral stems originated from the first cycle, the second cycle was started with the emission of new tillers.

During the experiment, with the development of the plants, three weight adjustments were performed. Furthermore, substrate samples were collected both on the surface as in depth $(10 \mathrm{~cm})$ for verifying the salt balance from the CE of the saturated extract.

Throughout the experimental period the following variables were evaluated: wateruse efficiency (EUA), as the ratio between the number of collected stems and the volume of water applied in each pot; harvested floral stems $(\mathrm{HC})$; ratio between harvest floral stems and the number of emitted tillers ( $\mathrm{HC} / \mathrm{NP}$ ); number of leaves (NF) in the tiller at the moment of emission of the floral stem; duration of the vegetative phase (DFV), represented as the interval in days between tiller emission and the emission of the floral stem; duration of the productive phase (DFP), accounting the number of days between the emission and the harvest point of the floral stem; total cycle (CT), represented by the sum of the DFV and DFP; floral stem length (CHF), measuring between the collar of the tiller (close to the substrate) and the apex of the floral stem; floral stem diameter (DH), measured with pachymeter $20 \mathrm{~cm}$ below the insertion of the first open bract; bract length (CB), measured between the base and the apex of the bract. Considering that the collar of the floral stem presents an approximately ellipsoid section shape, the area was calculated based on the smallest and highest diameter and, from this, an equivalent diameter to a circle was obtained, thus obtaining the equivalent diameter of the floral stem collar (DECH).

The data were subjected to the tests of homogeneity of variance (Bartlett) and normality of residuals (Shapiro-Wilk). The analysis of variance was performed and the means were adjusted by regression through the statistical softwares SISVAR 5.6 and SigmaPlot 11.0.

\section{Results and Discussion}

The first tiller emission occurred at 13 DAP, with daily emission of new tillers until the establishment of the treatments. From this moment, tiller emission oscillated as a function of the treatment. All replications reached maximum tiller density at 107, 134, 216 and 233 DAP in the treatments of $4,8,12$ and 16 tillers, respectively.

The pots with lower tiller density (4 and 8) initially emitted a higher number of tillers, compared to the denser ones (12 and 16). This is related to the stress to which the plant is subjected during the pruning, seen that the less dense pots had to go through this process before and with higher frequency than in the treatments of higher density. When performing population control, in adequate hydric and nutritional conditions, a stimulation is created in the plant for vegetative growth.

At 199 DAP it was observed that many tillers of the floor area were clearly in etiolation process. According to Paiva \& Almeida (2014), light is an essential factor in the production of the floral stem. These observations, associated to the fact that the tillers had already trespassed the stipulated time for emission of the floral stem (Costa et al. 2007), justified the change in the spacing between pots, thus increasing the availability of light.

Regarding water consumption, it was observed that the higher is the tiller density in the pot, the higher also is the applied volume of water. Considering that fertigations were performed at every irrigation event, the application of nutrients also increased in the same proportion (Table 3).

The irrigation frequency and the volume of water applied in each pot varied as a function of the evolution of the set: "tiller + root system". The highest irrigation frequency (Figure 1a) and 
volume of water applied (Figure 1b) were verified within the months of July and September of 2015, however, the month of July was the one that presented the lowest mean temperature in the experimental period. This is related to that fact the plants were with the maximum number of tillers in the pots. Many of these tillers were either in the end of the vegetative phase, or already in the productive phase, which confers it a higher hydric requirement. Felisberto et al. (2015), in a study performed in the São Francisco Valley with heliconia Golden Torch, verified that the crop coefficient (KC) of this cultivar was higher in the productive phase, surpassing in $60 \%$ the $\mathrm{Kc}$ of the initial phase.

Table 3. Water volume and mass of macro and micronutrients applied per pot in the cultivation of H. psittacorum L.f. cv. Red Opal, as a function of tiller density, during the entire cycle, in Petrolina/PE.

\begin{tabular}{ccccc}
\hline \multirow{2}{*}{ Variable } & \multicolumn{4}{c}{ Number of Tillers } \\
\cline { 2 - 5 } & 4 & 8 & 12 & 16 \\
\hline Water (I) & 647.36 & 941.46 & 1053.86 & 1095.25 \\
$\mathrm{~N}(\mathrm{~g})$ & 47.02 & 68.68 & 75.90 & 80.69 \\
$\mathrm{P}_{2} \mathrm{O}_{5}(\mathrm{~g})$ & 20.25 & 29.78 & 32.82 & 34.42 \\
$\mathrm{~K}_{2} \mathrm{O}(\mathrm{g})$ & 65.31 & 95.85 & 105.71 & 111.38 \\
$\mathrm{Mg}(\mathrm{g})$ & 2.74 & 4.02 & 4.43 & 4.69 \\
$\mathrm{~S}(\mathrm{~g})$ & 3.57 & 5.22 & 5.76 & 6.10 \\
$\mathrm{Zn}(\mathrm{g})$ & 0.274 & 0.402 & 0.443 & 0.469 \\
$\mathrm{Mn}(\mathrm{g})$ & 0.137 & 0.201 & 0.222 & 0.235 \\
$\mathrm{~B}(\mathrm{~g})$ & 0.082 & 0.120 & 0.133 & 0.141 \\
$\mathrm{Mo}(\mathrm{g})$ & 0.014 & 0.020 & 0.022 & 0.023 \\
\hline
\end{tabular}

a)

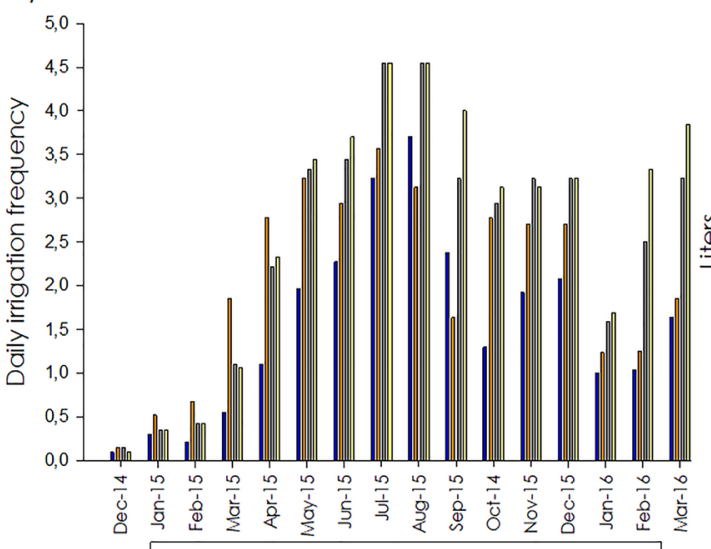

$\square$ Tillers $\square 8$ Tillers $\square 12$ Tillers $\square 16$ Tillers

Figure 1. a) Frequency of daily irrigation and b) volume of water applied throughout the cultivation of Heliconia psittacorum L.f. Red Opal in Petrolina - PE.

The mean temperature in the entire experimental period stood within the ideal range, which is between 21 and $35^{\circ} \mathrm{C}$, according to Paiva \& Almeida (2014). The authors also report that temperatures inferior to $15^{\circ} \mathrm{C}$ affect the vegetative development of the heliconias. In the experimental period, the lowest observed temperature was $15.8{ }^{\circ} \mathrm{C}$. Therefore, the temperature did not restrict the development of the plants.

The duration of the vegetative phase (DFV) of the first emitted tillers was superior compared to the remaining tillers in the pot b)

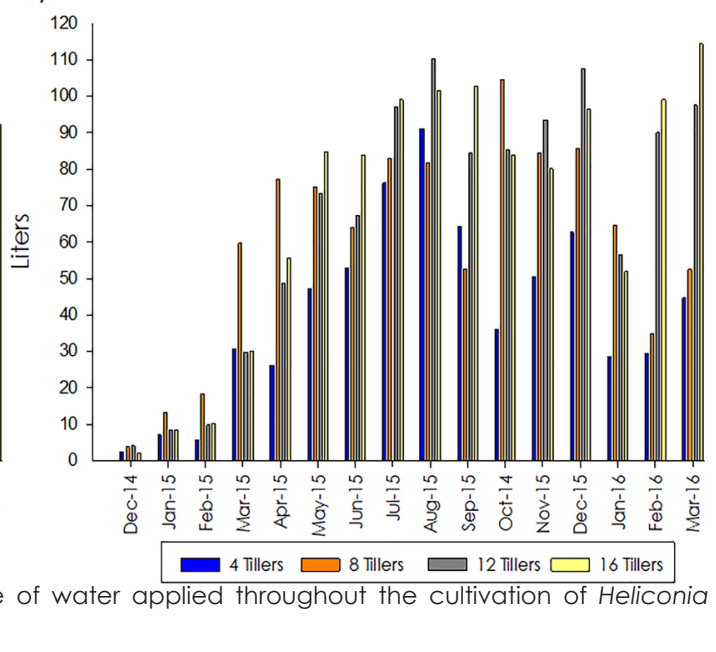

(Figure 2). This fact was observed in all treatments. The first tillers had a vegetative phase superior to 200 days, with a gradual reduction, until reaching values next to 160 days, tending to a stabilization.

Stabilization is evidenced from the emission of the fifth tiller in the treatment of lowest density, that is, it occurred only at the second cycle. In the remaining treatments, this stabilization occurred from the eight tiller. The same behavior was observed for the DFP and, consequently, for the total cycle in all treatments. This reduction in the number of days for the cited variables is related to the existence of a 

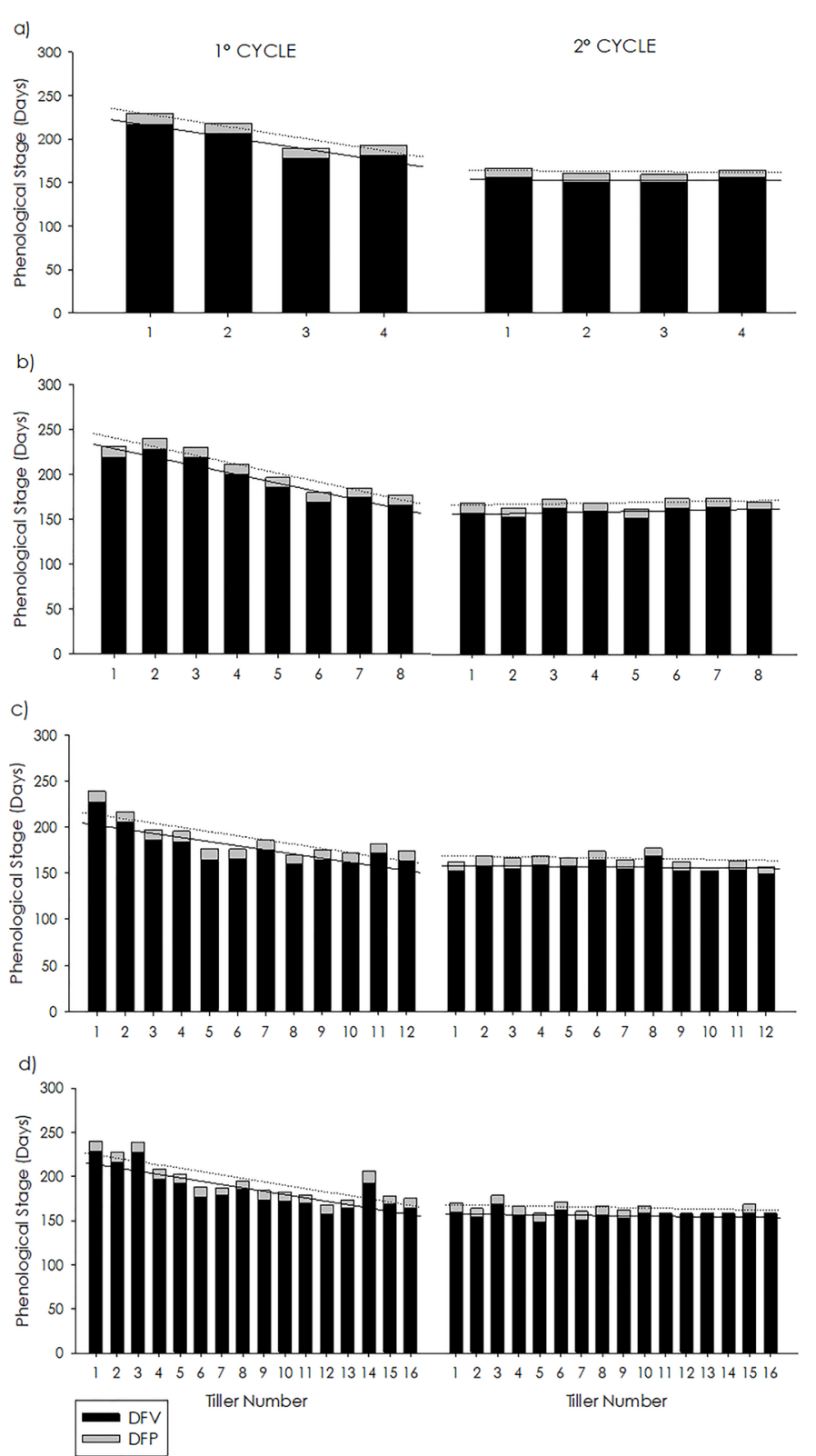

Figure 2. Duration of the vegetative phase (DFV), duration of the productive phase (DFP) and total cycle (CT) of the treatments a) 4, b) 8, c) 12 and d) 16 , in each evaluated tiller.

fully developed root system, thus occurring a higher efficiency in the absorption of water and nutrients.

The water-use efficiency (EUA) was monthly monitored starting from June (207 DAP), on the occasion of the harvest of the first floral stem (Figure 3a). During the first experimental cycle, the EUA value was constantly growing in all treatments throughout time. Until September $(270$ DAP), treatment 4 was the most efficient, being then overcome by that of 12 tillers. However, treatment 16 became the most efficient from $330 \mathrm{DAP}$, thus remaining until the end of the experiment.

In the period between October and January (299 and 390 DAP) there was a decrease in the EUA. This occurred as a function of the offseason period, characterized by the harvest of the floral stems of the first cycle and the tillers of the still developing second cycle. In the last experimental month, the treatments with higher tiller density presented higher EUA than the treatments of lower density; however, no significant difference was detected (Figure 3b). Treatment 12 presented a slight superiority over treatment 16 due to this last treatment being 
a)

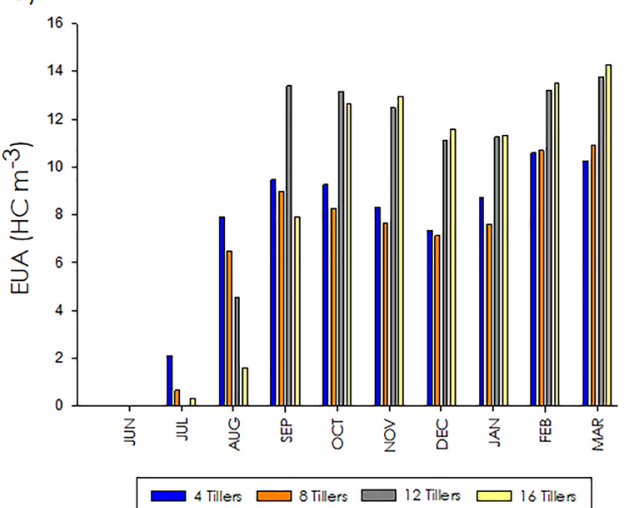

b)

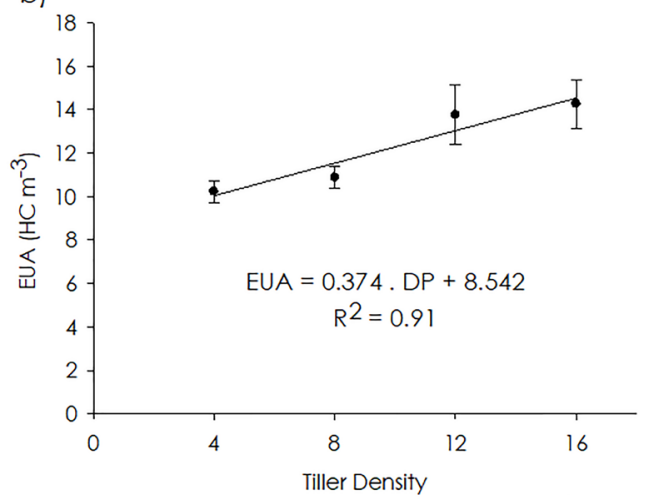

Figure 3. a) Monthly Water-Use Efficiency and b) Water-Use Efficiency in the cultivation of H. psittacorum L.f. cv. Red Opal in Petrolina/PE.

later as to the emission of the floral stem.

All treatments emitted floral stems. The harvested stems (HC) variable increased as a function of the higher density of tillers per pot, in an increasing linear trend (Figure $4 \mathrm{a}$ ). The ratio between the number of harvested floral stems and the total number of emitter tillers (HC/NP) had a decreasing linear trend (Figure 4b), with the pots with lower tiller density being the ones that obtained a higher ratio. In both variables there was significant difference among the treatments, with treatment 16 presenting the best mean of harvested floral stems (15.6 $\left.\mathrm{HC} \mathrm{pot}^{-1}\right)$, being $130 \%$ superior to treatment 4 , which obtained the lowest mean $\left(6.6 \mathrm{HC} \mathrm{pot}^{-1}\right)$. As to the $\mathrm{HC} / \mathrm{NP}$ ratio, treatment 4 stood out with $82.8 \%$, whereas treatment 16 presented a mean of $52.7 \%$.

The decreasing linear tendency of the relation $\mathrm{HC} / \mathrm{NP}$ is due to the fact that in the treatments of higher density, in spite of having more tillers, many of these did not reach the productive phase. This might be attached to the

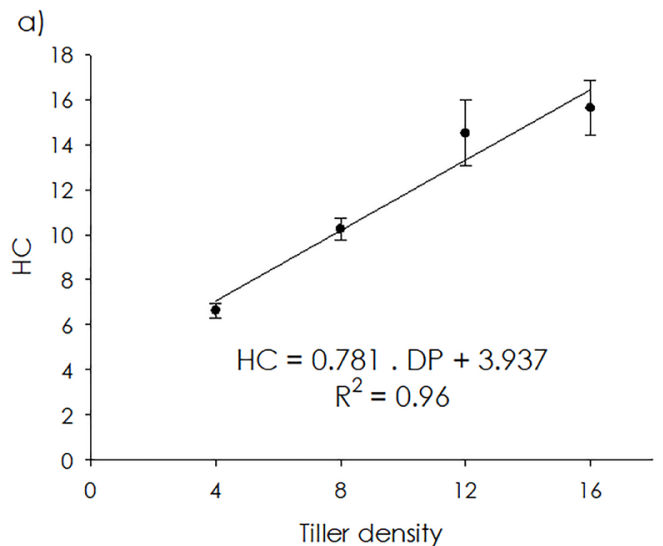

lower availability of solar irradiance promoted by the higher tiller density, besides of the greater competition for nutrients, with direct interference in the production of floral stems (Costa et al., 2006).

Considering that the emission of floral stems in pot-cultivated heliconias, especially in the cultivar Red Opal, presents in the literature results that are considered unsatisfactory, with nonexistent or irregular emission (Souza et. al., 2009; Santos et al., 2012; Gervásio \& Melo Junior, 2014), the data found in the present work are therefore considered innovative.

Sousa et al. (2011) when evaluating the saline content of the irrigation water in the cultivation of Heliconia psittacorum L.f. cv. Red Opal, also in 21-liter pots, although with soil (Neosol) and humus (2:1) as substrate, found a mean inferior to 10 tillers/pot, and a floral stem emission varying from 0 to $13 \%$ of the total of tillers as a function of the treatment. As to the present study, the production of stems in all treatments

b)

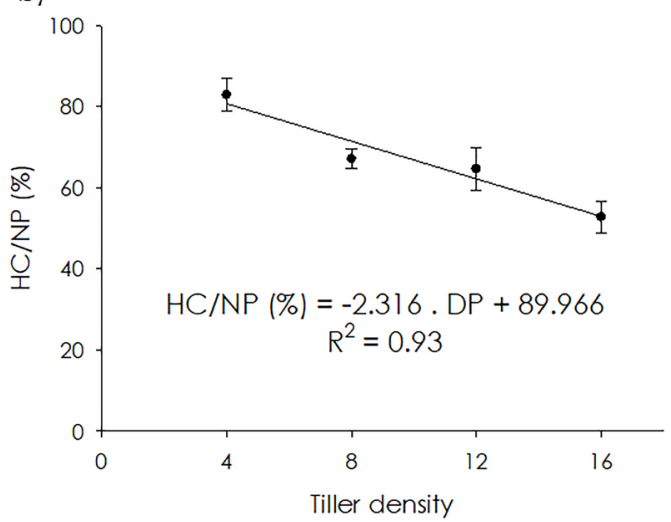

Figure 4. a) Number of harvested stems ( $\mathrm{HC}$ ) and b) ratio between the number of harvested stems and the number of emitted tillers (HC/NP) in the cultivation of H. psittacorum L.f. cv. Red Opal in Petrolina/PE. 
was successful, with the lowest production rate being superior to $50 \%$.

This success in stem production is related to the cultivation and management conditions. The coconut husk fiber presents good physicalhydric characteristics, with good porosity and water retention (Zorzeto et al., 2014). Potted cultivation requires the utilization of substrates with these attributes. The characterization of this material allowed to perform the management of irrigation/fertigation in an adequate manner, with a better utilization in the application of nutrients, thus avoiding its deficiency or excess.

Heliconias are plants that do not tolerate waterlogging, though they are very demanding as to water, with its pot-life being limited by inadequate irrigation during the production phase (Paiva \& Almeida, 2014). The same authors report that this crop is also very demanding as to nutrients, and requires good availability of light for the production of floral stems.

The NF variable had a decreasing linear trend, with the mean of treatment 4 being superior to the remaining treatments (Figure $5 a)$. Generally, the emission of the floral stems occurred after the opening of the eight leaf of the tiller. The number of leaves is directly linked to the photosynthetic process, with the acquisition of carbohydrates, being this factor essential in vegetal growth and development (Taiz \& Zeiger, 2009).

The variables DFV (Figure 5b) and CT (Figure 5c) did not present statistical difference among treatments. As for the DFP (Figure 5d), a decreasing tendency was observed with the increase in the number of tillers in the pot, with the mean of treatment 4 remaining one day more in this phase compared to the remaining treatments. The duration of the productive phase is also related to the point of harvest demanded by the consuming market, being dependent of the number of open bracts.

Costa et al. (2007) in an experiment under field conditions with cultivars and hybrids of $H$. psittacorum L.f. cv. Red Opal, observed average duration of the vegetative phase of 209 days, productive phase of 20 days and total cycle of 240 days. The variable DFV, in the present work, varied from a mean of 175 to 180 days, the DFP from 10 to 21 days and the total cycle with the highest mean of 192 days. As it may be observed, the means obtained in the experiment had values well below those presented by the cited authors, with such result being attributed to the adopted management techniques.

For the floral stem length (CHF) no significant statistical difference occurred among treatments, with mean values varying from 119 to $129 \mathrm{~cm}$ (Figure 6a). According to Ibraflor (2016), the quality control of tropical flowers demands a stem length higher than $90 \mathrm{~cm}$, whereas Paiva \& Almeida (2014) attribute $80 \mathrm{~cm}$ as a minimum value for commercialization. In this manner, all treatments presented values considered superior to those demanded by the market.

It may be noted that treatment 4 was the one with lesser CHF. For the remaining treatments, as a function of tiller density within the pot, a growing stimulation occurred to etiolation, which resulted in floral stems of greater length with reflected effect on $\mathrm{DH}$ and $\mathrm{DECH}$, with a linear decrease being observed in these variables as a function of the treatments.

For the $\mathrm{DH}$ a significant statistical difference was verified among treatments, with means varying from 8 to $9.2 \mathrm{~mm}$ (Figure 6b). Nowak \& Rudnicki (1990) affirm that stems with greater diameters tend to be more rigid, with positive post-harvest results, whereas Paiva \& Almeida (2014) suggest that this diameter must not be very great in order to avoid weight increase.

The DECH variable presented means varying from 18 to $21 \mathrm{~mm}$ (Figure 6c). The stems of treatment 4 and 8 tillers had diameters superior to the remaining treatments. According to Ibraflor (2016), the collar diameter of the floral stem must be superior to $20 \mathrm{~mm}$ in order to be framed into the quality standard demanded by the market. In the approached treatments, only treatment 16 presented inferior mean to this value, whereas treatment 12 presented bordering values.

In the floral stems from the second cycle, an unsheathing was detected in the pseudostem in around $4 \%$ of the harvested stems, thus reducing its diameter. This fact was verified in all treatments and contributed to the decrease of the mean of this variable. Stems with similar 
symptoms were verified by Paiva \& Almeida (2014), with its occurrence being attributed to nitrogen (N) deficiency. Castro et al. (2015) report that macronutrients are very important in the production of heliconias, especially the $\mathrm{N}$. The application of $K$ in an unbalanced manner with $\mathrm{N}$ might promote $\mathrm{N}$ deficiency through dilution effect (Novais et al., 2007). Although this symptom did not compromise the production of floral stems in a significant manner in this work, the development of studies that might clarify this phenomenon is highly important.

Bract length (CB) presented means varying from 19 to $21 \mathrm{~cm}$, with treatment 4 being responsible for the highest values (Figure $6 \mathrm{~d}$ ). Costa et al. (2007) reported that the mean length of $H$. psittacorum cv. Red Opal reached a mean value of $22 \mathrm{~cm}$, thus corroborating with the data found in this present experiment.

As verified, the qualitative variables $\mathrm{CB}, \mathrm{DH}$ and $\mathrm{DECH}$ were inversely proportional to the tiller density in the pot. Paiva \& Almeida (2014) report that the overcrowding of heliconias promotes a decline in the quality of the floral stems. a)

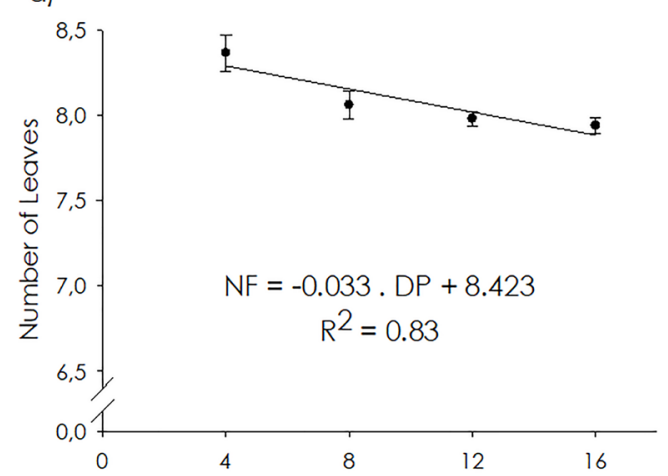

c)

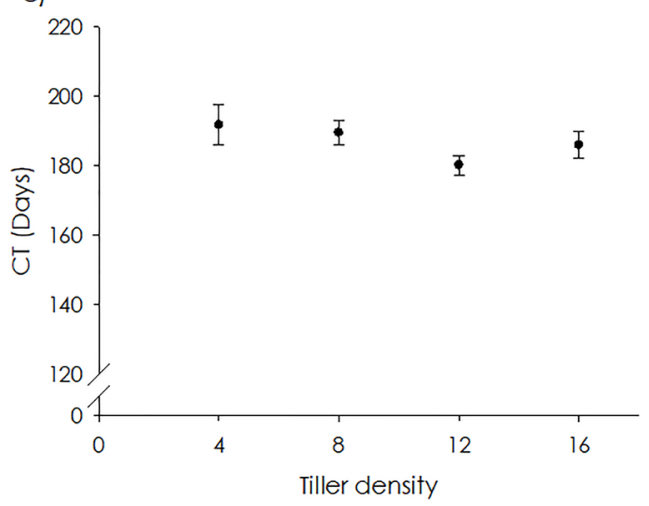

b)
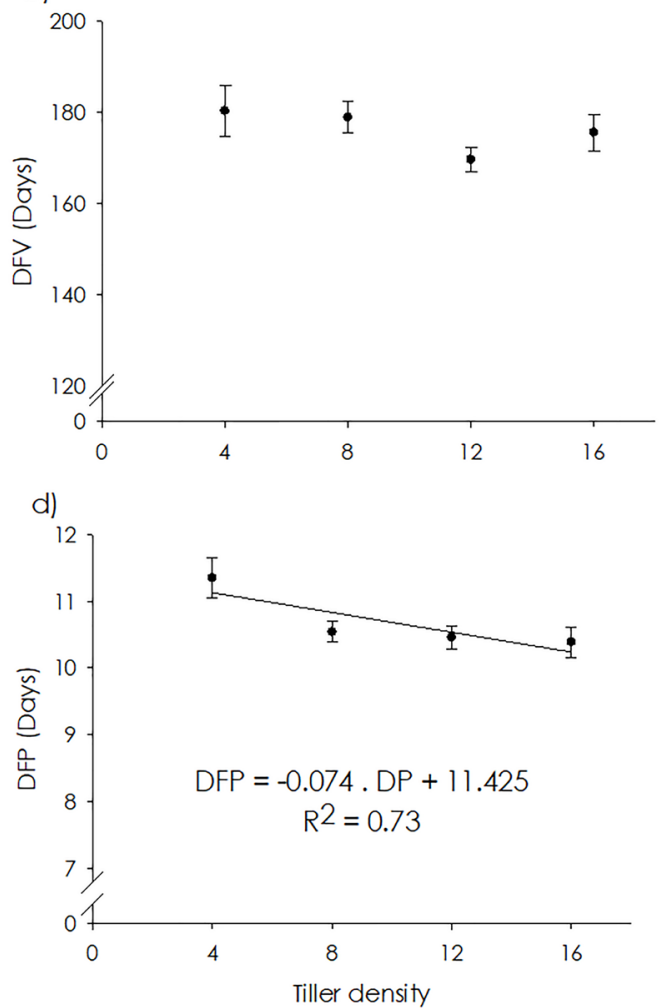

Figure 5. a) Number of Leaves (NF) at the moment of floral stem emission, b) duration of the vegetative phase (DFV), c) total cycle (CT), and d) duration of the productive phase (DFP) as a function the treatments in the cultivation of $H$. psittacorum L.f. cv. Red Opal in Petrolina/PE. 

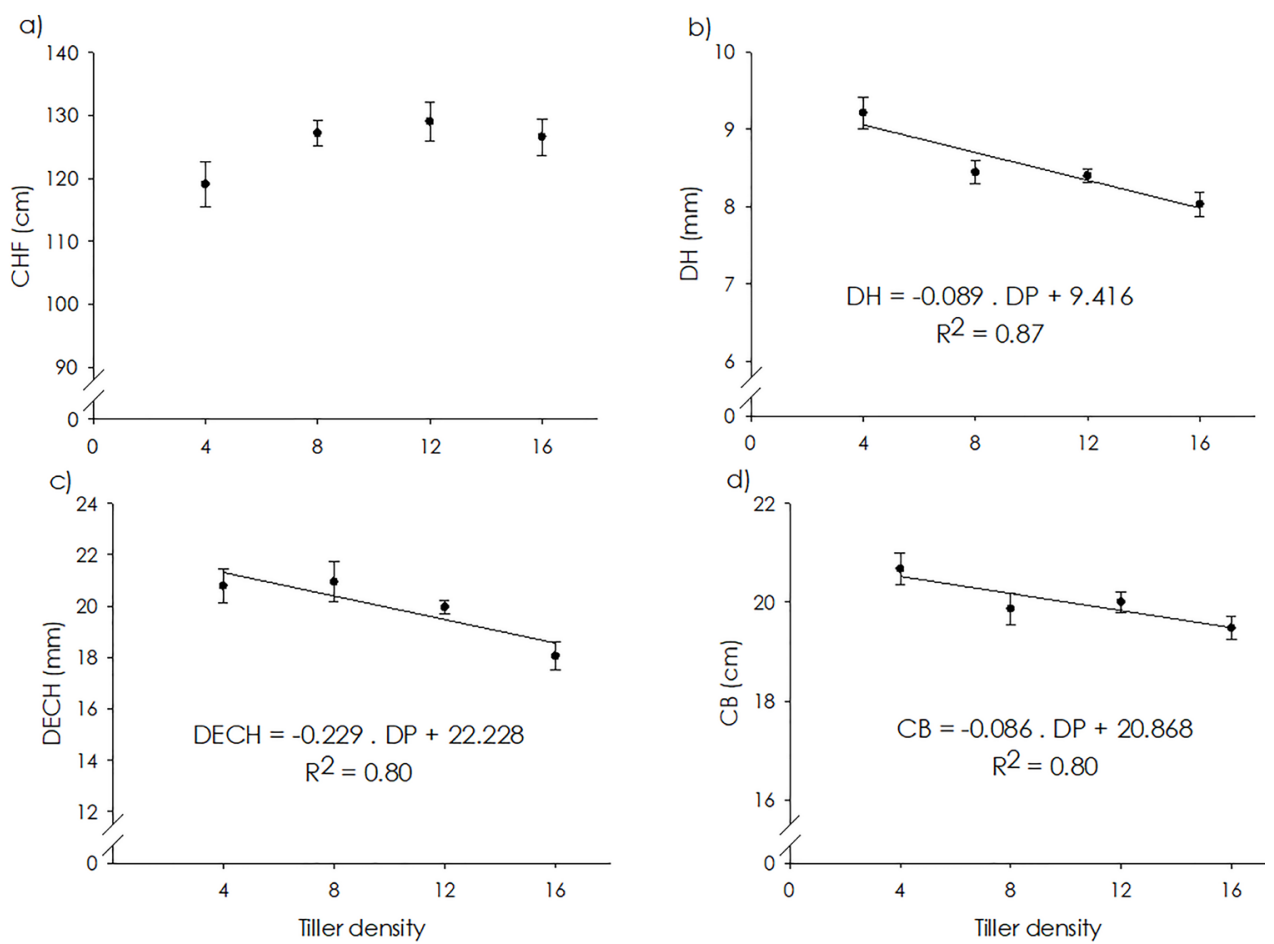

Figure 6. a) Floral stem length (CHF), b) floral stem diameter (DH), c) equivalent diameter of the floral stem collar (DECH) and d) bract length (CB) of H. psittacorum L.f. cv. Red Opal in Petrolina/PE.

\section{Conclusions}

Tiller density, within the established limits, was not the limiting factor for the emission of floral stems.

The density of 16 tillers pot $^{-1}$ provided the highest number of harvested stems (HC) and highest water-use efficiency (EUA); however, regarding the equivalent diameter (DECH) it does not provide to the market specifications.

The quality of the floral stems is inversely proportional to the tiller density within the pot.

The treatment with density of 12 tillers pot $^{-1}$ presented a high water-use efficiency (EUA), as well as it provided stems within the standards demanded by the market, being thus recommended for the cultivation of $H$. psittacorum cv. Red Opal in the conditions in which the present experiment was conducted.

\section{References}

Castro, A.C.R. Willadino, L.G. Castro, M.F.A. Aragão. F.A.S. 2015. Macronutrients deficiency in Heliconia psittacorum $x$ Heliconia spathocircinata 'Golden Torch'. Revista Ciência Agronômica 46: 258-265.

Carrijo, O.A.; Reis, N.V.B.; Makishima, N. 2002. Fibra da casca de coco verde como substrato agrícola. Horticultura Brasileira 20: 533-535.
Costa, A.S. Loges, V. Castro, A.C.R. Verona, A.L. Pessoa, C.O. Santos, V.F. 2006. Perfilhamento e expansão de touceiras de helicônias. Horticultura Brasileira 24: 460-463.

Costa, A.S. Loges, V. Castro, A.C.R. Bezerra, G.J.S.M. Santos, V.F. 2007. Variabilidade genética e correlações entre caracteres de cultivares e híbridos de Heliconia psittacorum. Revista Brasileira de Ciências Agrárias 2: 187-192.

Felisberto, T.S. Silva, D.O. Filho, J.R.S. Santos, W.J. Deon, M.D. Marinho, L.B. 2015. Evapotranspiração e coeficiente de cultivo da helicônia Golden Torch no Vale do São Francisco. Revista Brasileira de Agricultura Irrigada 9: 335-343.

Gervásio, E.S.; Melo Junior, J.C.F. 2014. Utilização da técnica de lisimetria de pesagem na automação de um sistema de irrigação localizada para uso no manejo da irrigação de cultivos em recipientes. Rev. Irriga 19: 626-640.

Gomes, A.R.M. D'ávila, J.H.T. Gondim, R.S. Bezerra, F.C. Bezerra, F.M.L. 2006. Estimativa da evapotranspiração e coeficiente de cultivo da Heliconia psittacorum $L \times H$. spathocircinada (Arist) cultivada em ambiente protegido. Revista Ciência Agronômica 37: 13-18.

Gondim, R.S. Gomes, A.R.M. Bezerra, F.C. Costa, C.A.G. Pereira, N.S. 2008. Estimativa da evapotranspiração e coeficiente de cultivo da Heliconia bihai L., cultivada em ambiente protegido. Revista Brasileira de Horticultura 
Ornamental 14: 53-58.

para plantas. Bragantia 73: 300-311.

Junqueira, A. H.; Peetz, M.S. 2008. Análise conjuntural da evolução das exportações de flores e plantas ornamentais do Brasil - janeiro a dezembro de 2007. Revista Brasileira de Horticultura Ornamental 14: 37-52.

IBRAFLOR. Instituto Brasileiro de Floricultura. $2016 . \quad$ http://ibraflor.com/publicacoes/ vw.php? cod=73<Acesso em 03 Abr. 2016>

Nomura, E.S. 2008. Diagnóstico da produção de flores tropicais na região do Vale do Ribeira. Revista Brasileira de Horticultura Ornamental 14: 23-25.

Novais, R.F. V, V.H.A. Barros, N.F. Fontes, R.L. Cantarutti, R.B. Neves, J.C.L. 2007. Fertilidade do Solo. Sociedade Brasileira de Ciências do Solo. Viçosa, BRA. 1017p.

Nowak, J.; Rudnicki, R.M. 1990. Postharvest handling and storage of cut flowers, florist greens and potted plants. Timber Press. Portland,USA. $210 \mathrm{p}$.

Paiva, P.D.O; Almeida, E.F.A. 2014. Produção de Flores de Corte. Ed. UFLA. Lavras, BRA. 678p.

Rhoades, J.D.; Kandiah, A.; Mashali, A.M. 1992. Uso de águas salinas para produção agrícola. Tradução de Gheyi, H.R.; Sousa, J.R.; Queiroz, J.E. UFPB. Campina Grande, BRA. 117p.

Santos, O.S.N.; Paz, V.P.S.; Gloaguen, T.V.; Teixeira, M.B.; Fadigas, F.S.; Costa, J.A. 2012. Crescimento e estado nutricional de helicônia irrigada com água residuária tratada em casa de vegetação. Revista Brasileira de Engenharia Agrícola e Ambiental, 16: 820-827.

Sousa, A.E.C.; Soares, F.A.L.; Gheyi, H.R.; Barros, H.M.M.; Nascimento, E.C.S.; Andrade, L.O. 2011. Salinidade da água de irrigação na aclimatização de mudas, desenvolvimento e produção de heliconias. Revista Brasileira de Agricultura Irrigada 5: 328-336.

Souza, G.O., Viégas, I.J.M., Frazão, D.A.C. 2009. Crescimento de Heliconia psittacorum cv. Golden Torch em Função de Doses de Calcário Dolomítico. Ciências e Agrárias 52: 49-59.

Souza, R.R. Cavalcante, M.Z.B.; Silva, A.A.; Silva, E.M. Brito, L.P.S.; Silva, A.O. 2016. Yield and quality of inflorescences of 'Golden Torch' helicônia in different shaded environments. Revista Brasileira de Engenharia Agrícola e Ambiental 20: 128-132.

Taiz, L.; Zeiger, E. 2009. Fisiologia vegetal. Armed. Porto Alegre, BRA. 848p.

Zorzeto, T.Q. Dechen, S.C.F. Abreu, M.F. Júnior, F.F. 2014. Caracterização física de substratos 